\title{
The occurrence of Nematalycidae (Acari, Prostigmata) in Central Amazonia with a description of a new genus and species
}

\author{
Herbert O. R. Schubart (") \\ Instituto Nacional de Pesquisas \\ da Amazônia
}

\begin{abstract}
A new genus and species of Nematalycidae (Acari) found near Manaus, Brazil, are described in this paper. This is the first find of the family in the Neotropical Region. A new generic name is proposed for the species described by Cunliffe in 1956.
\end{abstract}

\section{INTRODUCTION}

During a survey of the microarthropods in the sandy soils under the vegetation known as "Campina", situated near Manaus, Brazil, I found very interesting mites of the family Nematalycidae Strenzke. This is, to my knowledge, the first reported occurence of this group in the Neotropics, and it greatly enlarges the known geographic distribution of these mites. After I examined them I found them to be representatives of a new genus and species, which I describe below. A comparison of the distribution, habitat and morphological characters of the known species of the family, presented at the conclusion, suggests a new generic arrangement. Accordingly, I propose a new genus name for the species described by Cunliffe in 1956 .

\section{MATERIAL AND METHODS}

One sample, consisting of 4 adults and 1 nymph, was obtained in the "Reserva Biológica de Campina" of INPA, at Km 60 of the Manaus-Caracarai road, in February and March 1973, during a study of three vertical soil profiles, each reaching the groundwater table (1.30 $\mathrm{m}$ to $4 \mathrm{~m}$ deep). These soils (regosols) were sandy in the whole profile, with some organic matter in the superficial horizons. The mites were found only at the top of the prosile, the deepest occurrence being at $25 \mathrm{~cm}$.

A second sample was collected in a ver, disturbed, once burned, Campina, at Km 19 of the same road, in September 1973. The soil sample taken to a depth of $10 \mathrm{~cm}$, consisted of fine sand, rich in organic matter and roots, under a mat of lichens.

All mites were extracted from the soil samples with the aid of simple Tullgren funnels, and are preserved in lactophenol. The sex of the specimens has not yet been established.

\section{Psammolycus gen. $n$.}

Type species: Psammolycus delamarei $\mathrm{sp} . \mathrm{n}$.

Diagnosis: Moderately elongate, compared to Gordialycus Coineau et al., 1967. Chaetotaxy of idiosoma numerically well developed Annulations showing a zigzag pattern, with very faint microtubercles. Apotele with two lateral claws and a ciliated empodium on all legs. Two pairs of bilobed genital discs Chelicera with opposed chelae and a trochanter. Palp in four segments, with a solenidium on the tarsus forming a "corne double" with a dorsal seta. An external podocephalic canal present. A gland opens into the podocephalic canal above the coxa I. 


\section{Psammolycus delamarei sp.n. ( $\left.{ }^{*}\right)$}

Holotype: An adult specimen selected from the first sample cited above, deposited in the collection of INPA

Measurements : Length of the idiosoma of the adults measured on the 13 specimens of the second sample: range 410-515 $\mu$, mean $469.6 \mu$, coefficient of variability $7.13 \%$, Dia meter of the hysterosoma: range 50-70 $\mu$. mean $60.4 \mu$.

\section{Description of the adults}

Tegument, general aspect: Colour whitish in alcohol. All fixed specimens show a characteristic J-shape (Fig.1, A). Tegument ornamented with transversal zigzag ridges, bearing very faint microtubercles (Fig. 1, B), all over the idiosoma, with the exceptions of the areas above the genital area and above the legs, which bear longitudinal ridges (Fig.1, A). Prodorsum with few smooth longitudinal ridges in its central part. The striae on the legs I and II (not represented on Fig. 1, E) are smooth.

Idiosoma: Prodorsum with lateral depressions and bearing very elongate setae (Fig. 1, D); $p t$ is an odd seta, not furcate, with two small teeth at the base; $p a, p b$ and pe are bifurcate. All the setae shown on Fig. 1, A are constant numerically, except the one indicated with $x$, which may be present or not. The anal setae are variable, being generally trifurcate. All the other setae are bifurcate with two small teeth at the base of the furcation (Fig. 1, B). One specimen was observed with one of those setae completely trifurcate. All setae are birefringent, indicating the presence of actinochitin.

Genital area with two genital and two aggenital setae. Two pairs of genital discs are present, which have an unusual bilobed structure (Fig. 1, C).

Epimeral formula (Fig. 1, F): 3-2-3-2,3.

Gnathosoma and lateral parts of podosoma: The infracapitulum was not studied. The pharynx extends, as a fine tube of about $1 \mu$ diameter, as far as the region of leg III. Chelicera (Fig. 1, H) with a dorsal seta and opposed chelae, weakly sclerotized; fixed digit has a clawlike prolongation at its tip; a trochanter (Fig. 1, H: TR) is well developed. Palp with four segments; on the tarsus a conspicuous structure is seen: this is a large solenidium, forming a "corne double" with a dorsal seta.

An external podocephalic canal is present; a gland opens into the podocephalic canal above coxa 1.

Legs: Femora of legs I and II divided in two. Apotele of all legs consisting of two lateral claws and one ciliated empodium. Tarsal lyrifissure present on leg 1 . Solenidial formulae (beginning from the tarsi): I (2-2-2-0-0); II $(2-0-1-0-0) ;$ III $(0-0-1-0) ; \quad$ IV $(0-0-0-0)$. Portions of legs I and II are striated, as indicated on Fig.1, D (on Fig. 1, E the striae were omitted).

RELATIONSHIPS BETWEEN THE KNOWN SPECIES OF NEMATALYCIDAE

The table 1 summarizes the data on distribution, habitat and morphological characters of the family. The group seems to be widely distributed. The disjunctive appearance of the distribution is probably due to insufficient collections. The paiearctic species are members of the interstitial fauna of subterranean waters, while the New World species are found in the superficial horizons of the soil. These differences in habitat may well be correlated, respectively, with the reduction or nonreduction of the chaetotaxy of the idiosoma. Considering the other morphological characters, the four species form a heterogeneous group, suggesting that they are distantly related. Therefore, I am proposing a new generic name for the species described by Cunliffe in 1956 :

\section{Cunliffea gen. $\mathrm{n}$.}

Type species: Nematalycus strenzkei Cunliffe, 1956.

Diagnosis: The characters that are listed on the table 1.

(*) - The species is named after Professor Cl. Delamare Debouteville, Paris. 


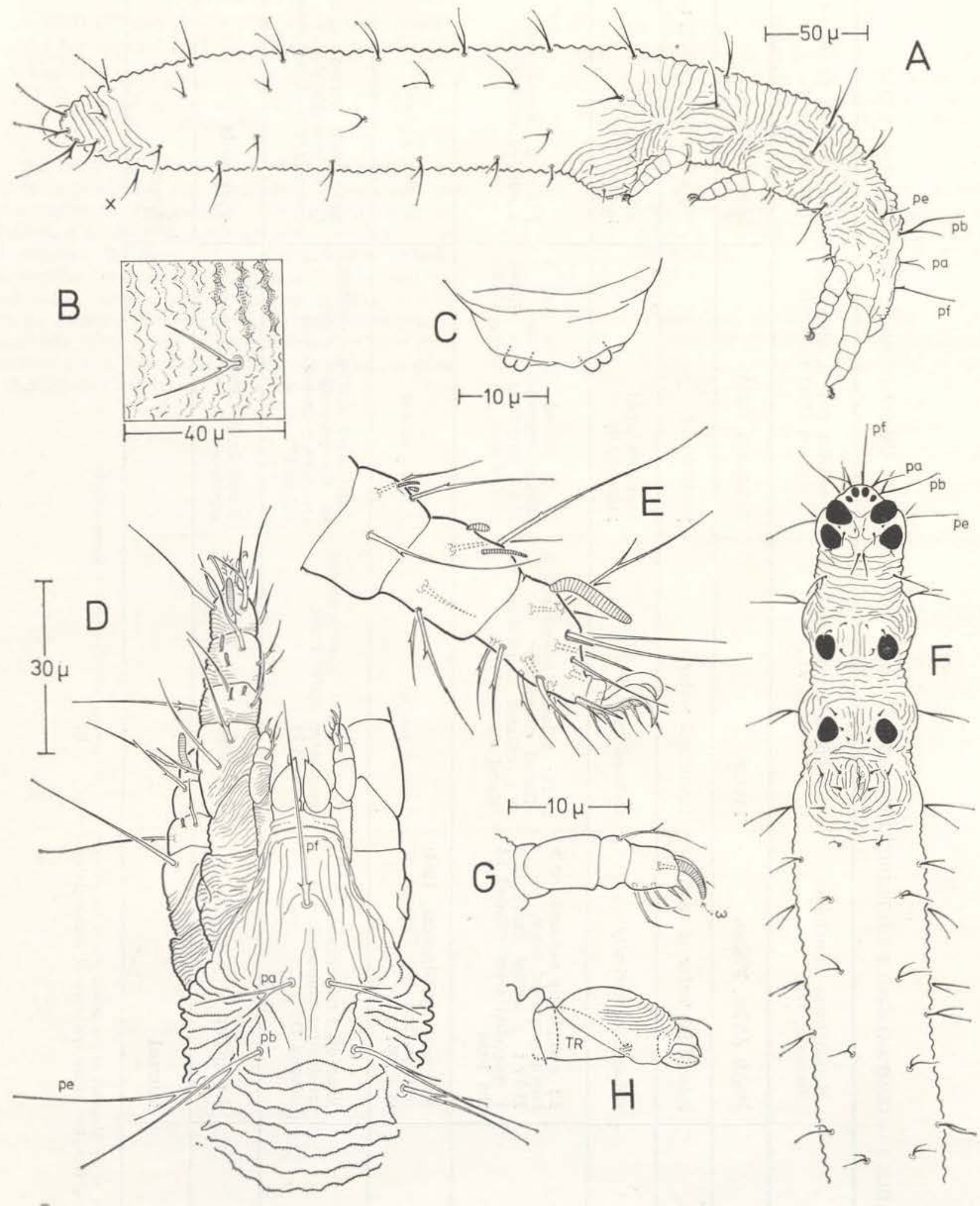

Fig. 1-Psammolycus delamarei gen. n., sp. n. A: General aspect of adult, lateral view. B; Detail of ornamentation and of a seta on hysterosoma. C: Genital lobe with genital discs, lateral. D: Dorsal view of prodorsum, gnathosoma and legs I - II. E: Extremity of leg I, antiaxia' $F$ : ventral view of adult. $G$ : Palp, antiaxial. $H$ : Chelicera, antiaxial. (A and $F$, and $E, G$ and $H$, respectively, to the same scale). 
TABLE 1 - COMPARISON OF DISTRIBUTION, HABITAT AND MORPHOLOGICAL CHARACTERS OF THE NEMATALYCIDAF

\begin{tabular}{|c|c|c|c|c|}
\hline & $\begin{array}{l}\text { Nematalycus nematoides } \\
\text { Strenzke, } 1954\end{array}$ & $\begin{array}{l}\text { Gordialycus tuzetae } \\
\text { Coineau et al., } 1967\end{array}$ & $\begin{array}{l}\text { Cunliffea gen. n. strenzkei } \\
\text { (Cunliffe, 1956) n. comb. }\end{array}$ & $\begin{array}{l}\text { Psammolycus delamarei } \\
\text { gen. n., sp. n. }\end{array}$ \\
\hline Distribution & North Africa, France & France & Oklahoma (USA) & Manaus (Brazil) \\
\hline Habitat & interstitial water in sand & interstitial water & pasture soil & top horizons of sandy roils \\
\hline $\begin{array}{l}\text { Chaetotaxy } \\
\text { of idiosoma }\end{array}$ & reduced numerically & reduced numerically & $\begin{array}{l}\text { well developed } \\
\text { numerically }\end{array}$ & $\begin{array}{l}\text { well developed } \\
\text { numerically }\end{array}$ \\
\hline Apotele & $\begin{array}{l}\text { I : completely reduced, or a } \\
\text { small empodial claw; } \\
\text { II-IV : } 2 \text { lateral claws and } \\
1 \text { empodial claw ciliated at } \\
\text { the base }\end{array}$ & $\begin{array}{l}\text { I-III : } 2 \text { lateral claws and a } \\
\text { ciliated empodium; } \\
\text { IV : ciliated empodium, no } \\
\text { lateral claws (") }\end{array}$ & $\begin{array}{l}\text { I: } 2 \text { lateral claws and } 1 \\
\text { simple empodial claw; } \\
\text { II-IV: empodial claw ciliated } \\
\text { at the base, no lateral claws }\end{array}$ & $\begin{array}{l}\text { I-IV : } 2 \text { lateral claws and } \\
\text { a ciliated empodium }\end{array}$ \\
\hline $\begin{array}{l}\text { Genital } \\
\text { discs }\end{array}$ & $\begin{array}{l}\text { not seen by Strenzke, } 1954 \text {; } \\
\text { undescribed by Coineau et } \\
\text { al., } 1967\end{array}$ & 2 pairs, simple & 3 pairs, simple & 2 pairs, bilobed \\
\hline Chelicera & $\begin{array}{l}\text { fixed digit membranous }\left({ }^{* *}\right) \text {; } \\
\text { trochanter undescribed } \\
\text { (absent ?) }\end{array}$ & $\begin{array}{l}\text { fixed dig it membranous; } \\
\text { trochanter undescribed } \\
\text { (absent?) }\end{array}$ & $\begin{array}{l}\text { fixod digit normal, opposed } \\
\text { to the movable digit; } \\
\text { trochanter undescribed } \\
\text { (absent?) }\end{array}$ & $\begin{array}{l}\text { fixed digit normal, opposed } \\
\text { to the movable digit: } \\
\text { trochanter well developed }\end{array}$ \\
\hline Palp & 1 segment & 4 segments & $\begin{array}{l}2 \text { segments, almost } \\
\text { coalesced }\end{array}$ & 4 segments \\
\hline $\begin{array}{l}\text { Podocephalic } \\
\text { canal }\end{array}$ & internal & $\cdots$ & $\ldots$ & external \\
\hline
\end{tabular}

1.) - According to the diagnosis of the genus, not to the description of the species, which contains a lapsus calomi

(V) - "mors fixe ordinaire" in the specimens of France (Coineau et al., 1967). 


\section{ACKNOWLEDGMENTS}

I wish to express my thanks to Mrs. Anne Prance for having had the patience to correct the English.

\section{RESUMO}

Um novo representante de Nematalycidae (Acari) foi encontrado nos horizontes superficiais de solos arenosos (regossolos) nas proximidades de Manaus, e é descrito como gênero e espécie novos no presente trabalho. Este é o primeiro achado da familia na Região Neotropical. Uma comparação das espécies conhecidas da familia mostra que as mesmas formam um conjunto heterogêneo, sugerinđo uma nova divisão genérica. Como con. sequiência, um novo nome genérico é proposto para a espécie descrita por Cunliffe em 1956.

\section{LTTERATURE CITED}

Corneau, $\mathrm{Y}_{\text {., et }}$ alii

1967 - Découverte en France des Acariens Nematalycidae Strenzke à l'occasion des travaux d'aménagement du Languedoc-Roussillon. C.R.Acad.Sc.Paris, 265:685-688.

CUNLIFFE, F.

1956 - A new species of Nematalycus Strenzke with notes on the family (Acarina, Nematalycidae). Proc.Ent.Soc.Wash., 58(6): 353-355.

STRENZKE, K.

1954 - Nematalycus nematoides n. gen. n. sp. (Acarina, Trombidiformes) aus dem Grundwasser der algerischen Küste. Vie et Mili$e u, 4(4): 638.647$. 